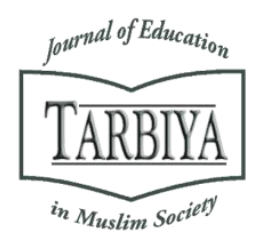

Available online at TARBIYA: Journal of Education in Muslim Society Website:

http://journal.uinjkt.ac.id/index.php/tarbiya

TARBIYA: Journal of Education in Muslim Society, 7(2), 2020, 252-259

\title{
ELEMENTARY MATH LEARNING DESIGN: AN INTEGRATION WITH ISLAMIC ENVIRONMENTAL ETHICS IN THE FIRST GRADE
}

Luluk Mauluah ${ }^{1}$, Marsigit ${ }^{2}$, Muhammad Nur Wangid ${ }^{3}$

${ }^{1}$ UIN Sunan Kalijaga Yogyakarta, Indonesia

${ }^{2,3}$ Universitas Negeri Yogyakarta, Indonesia

E-mail: mauluah@gmail.com

Received: $25^{\text {th }}$ September 2020; Revised: $14^{\text {th }}$ November 2020; Accepted: $28^{\text {th }}$ December 2020

\section{Abstract}

This research discusses the design of mathematics learning based on Islamic Environmental Ethics (IEE). The purpose of the research was to discover how to implement IEE in elementary mathematics learning, especially grade 1 . This qualitative research method begins with the analysis of condition grade 1 to 6 . By analyzing the themes of grade 1 to grade 6 , then themes are qualified percentage according to the use of terms related to Islamic Environmental Ethics (IEE) and after that, compiled a matrix containing competencies, classes, activities and assessments to implement it. The results of this study are, the first year has the lowest percentage of $32.5 \%$ of its IEE content so it needs to be developed. From the selection of basic competencies, 3.5, 4.5, 3.6 and 4.6 are selected for their implementation. The implications obtained by the IEE component concerning Islamic concern for the earth, especially those listed in the hadith on cleanliness. Based on the hadith, learning activities are arranged using used goods at worksheet one and worksheet 2. Based on its activities, assessment is prepared through rubrics, performance assessments and questionnaires.

Keywords: basic competencies; Islamic environmental ethics; mathematics learning; used goods

\section{Abstrak}

Penelitian ini membahas tentang desain pembelajaran matematika berbasis Islamic Environmental Ethics (IEE). Tujuan dari penelitian ini adalah untuk mengetahui bagaimana penerapan IEE pada pembelajaran matematika SD khususnya kelas 1. Metode penelitian kualitatif ini diawali dengan analisis kondisi kelas 1 sampai dengan kelas 6. Dengan menganalisis tema dari kelas 1 sampai dengan kelas 6 , maka tema tersebut memenuhi syarat. persentase sesuai penggunaan istilah terkait Islamic Environmental Ethics (IEE) dan setelah itu disusun matriks yang berisi kompetensi, kelas, kegiatan dan penilaian untuk mengimplementasikannya. Hasil dari penelitian ini, tahun pertama memiliki persentase terendah yaitu 32,5\% konten IEE-nya sehingga perlu dikembangkan. Dari pemilihan kompetensi dasar tersebut dipilih 3.5, 4.5, 3.6 dan 4.6 untuk pelaksanaannya. Implikasi yang diperoleh komponen IEE tentang kepedulian Islam terhadap bumi, terutama yang tercantum dalam hadits tentang kebersihan. Berdasarkan hadits, kegiatan pembelajaran disusun dengan menggunakan barang bekas pada lembar kerja satu dan lembar kerja dua. Berdasarkan kegiatannya disusun penilaian melalui rubrik, penilaian kinerja dan angket.

Kata kunci: kompetensi dasar; etika lingkungan islam; pembelajaran matematika; barang bekas

How to Cite: Mauluah, L., Marsigit, Wangid, M. N. (2020). Elementary Math Learning Design: An Integration with Islamic Environmental Ethics in the First Grade. TARBIYA: Journal of Education in Muslim Society, 7(2), 241-251. doi:10.15408/tjems.v7i2.19975.

Permalink/DOI: http://dx.doi.org/10.15408/tjems.v7i2.19975 


\section{Introduction}

The struggle to care for the environment has been passed for decades in America, Europe and Asia (McCrea, 2010); (Mohamed, 2012) The world of education has seriously formulated it, among others in the following programs: Environmental Education, Education for Sustainability Development, Education for Sustainability, Education for Sustainability in early childhood, etc.

By the way, Islam is not left behind, too, giving great attention to environmental concerns (Harahap, 2015) Among other things, Islam has principles of how people adherents behave towards the water, air, earth, animals and plants (Sarvestani, 2008; Shaikh, 2018; Gul \& Ali, 2018).

These items contained in the ethics of the environment contained in religion which originally pioneered through Islamic Environmental Education (Khalid \& Thani, 2007) and then environmental ethics in Islam (Islam and the environment: ethics and practice), which Fazlun Khalid calls in the 15th General Conference, September 27-29, 2010, with the theme: The Environment in Islam (Khalid, 2010) Islamic values govern human behavior regarding the environment. Not only regarding human relations with humans but guides how humans should treat plants, animals, water, soil (earth), air, and so on. (Manoiu et al, 2016).

The ethical values of environmental education are the responsibility of educators to be disseminated to students. In the implementation of learning, it will be significant to convey the importance of caring for the environment. For primary school level education, it needs to be thought about how to organize learning that can be carried out effectively, encouraging the growth of caring for the environment while encouraging awareness of religious values associated with environmental preservation.

The implementation of primary school learning in Indonesia uses integrative thematic learning based on the 2013 curriculum. This is because thematic learning has many benefits, including effectively improving performance (Kasiyati \& Zulmiyetri, 2018) exceptionally mild intellectual disability students can improve student communication skills (Ashokan \& Venugopal, 2016), also improve students' social skills (Ulum, 2018)

In the implementation of thematic learning, all subjects are served theme by theme, including learning mathematics. Mathematics learning is considered irrelevant if it is related to the environment. This doesn't seem right (JIANGUO, 2004). Many uses of mathematics benefit from human life, meaning that it benefits the environment, and many mathematical studies relating to human life and nature. (Dilao, 2004; Sontag, 2005; Spiegel, 2002; Marantika, 2018)

However, the integration of Islamic values into math learning is not optimal yet. Especially concerning Islamic values regarding environmental awareness. There are examples of learning mathematics and science that are integrated with Islamic values (REF1-2) but not about the value of environmental care. There is also an integration of environmental concerns in learning, but it is not viewed in an Islamic way of thinking (REF 1-2). So there is a high need in designing mathematics learning based on Islamic Environmental Ethics, especially at the elementary school level. This paper will find a solution to this problem. In other words, this paper is essential in answering what kind of mathematics learning design in elementary thematic learning, which can integrate Islamic ethical values about environmental care. 


\section{Method}

This type of research is qualitative by exploring and reviewing the literature. The method used the literature review method and added with the initial stage of $R \mathrm{n} D$, namely the Define and design steps of the Thiagarajan 4D development. The design is as follows: First: Exploration and examining primary sources of international journals on IEE values. Second, assessing the level of urgency for the integration of Islamic values (Define stage) After that, THE third: the Design stage: compiling a matrix of basic competencies, IEE values, activities and assessments. The next step is designing the worksheet for learning. The development stage has not yet completed the Develop and Disseminate stages, so the instrument is enough by researcher to collect, select, sort, and categorize the data obtained. Validation instruments, trial assessments do not yet exist or have not been carried out.

\section{Results and Discussion}

\section{Analysis of the first grade's themes and} activity-based implementation framework

In applying the values of environmental ethics in Islam to the learning of mathematics, it starts with reviewing the themes in the teacher and student books related to the critical words of Islamic Environmental Ethics based on the theory of Manoiu (2016), Shaikh (2018) and Harahap (2015). Keyword-based analysis of the theme with Islamic Environmental Ethics Manoiu (Ethics on Water, air, earth, animals, plants) presents in table 1.

Table 1. Analysis of Themes at First Year to Sixth

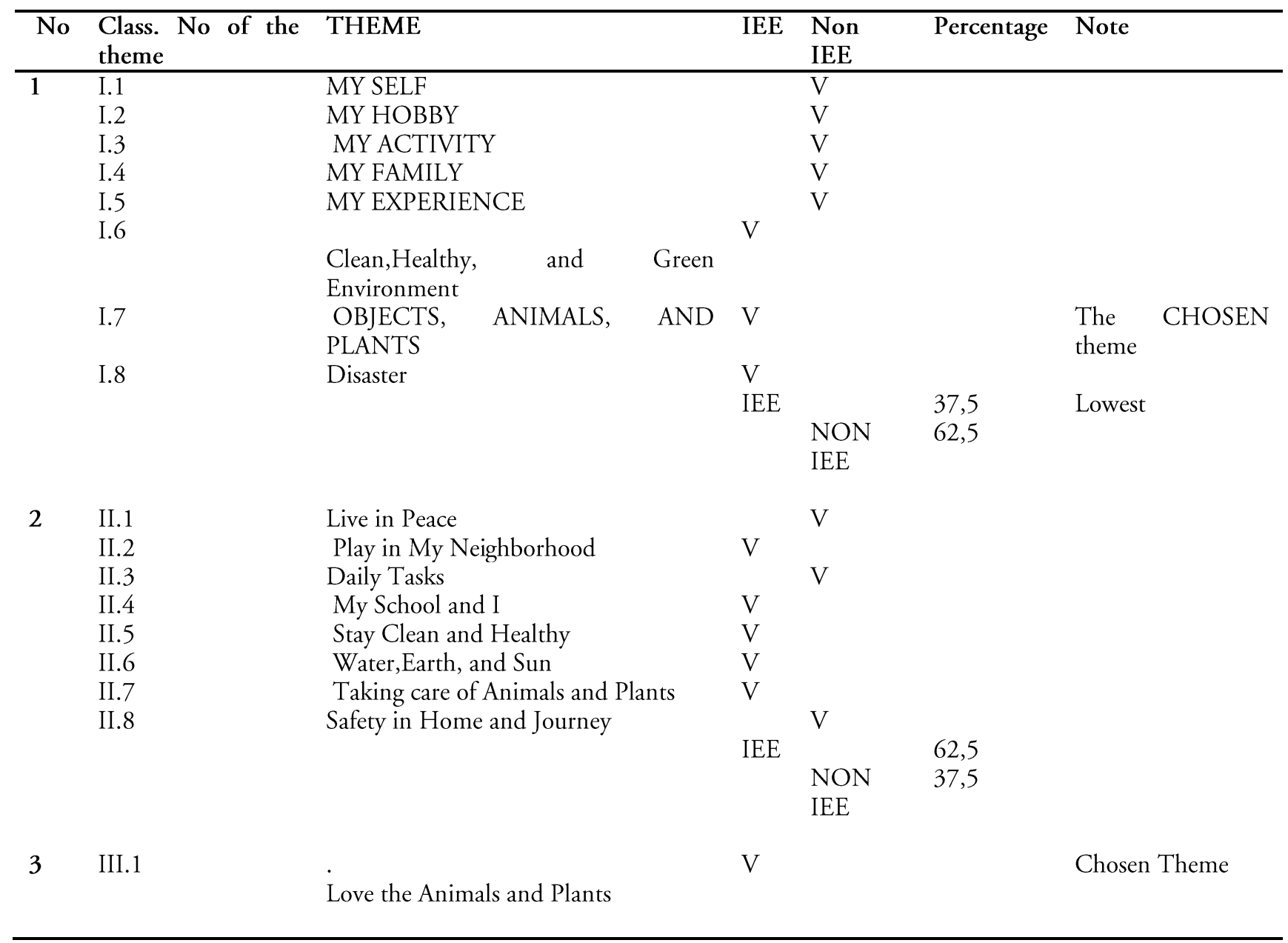




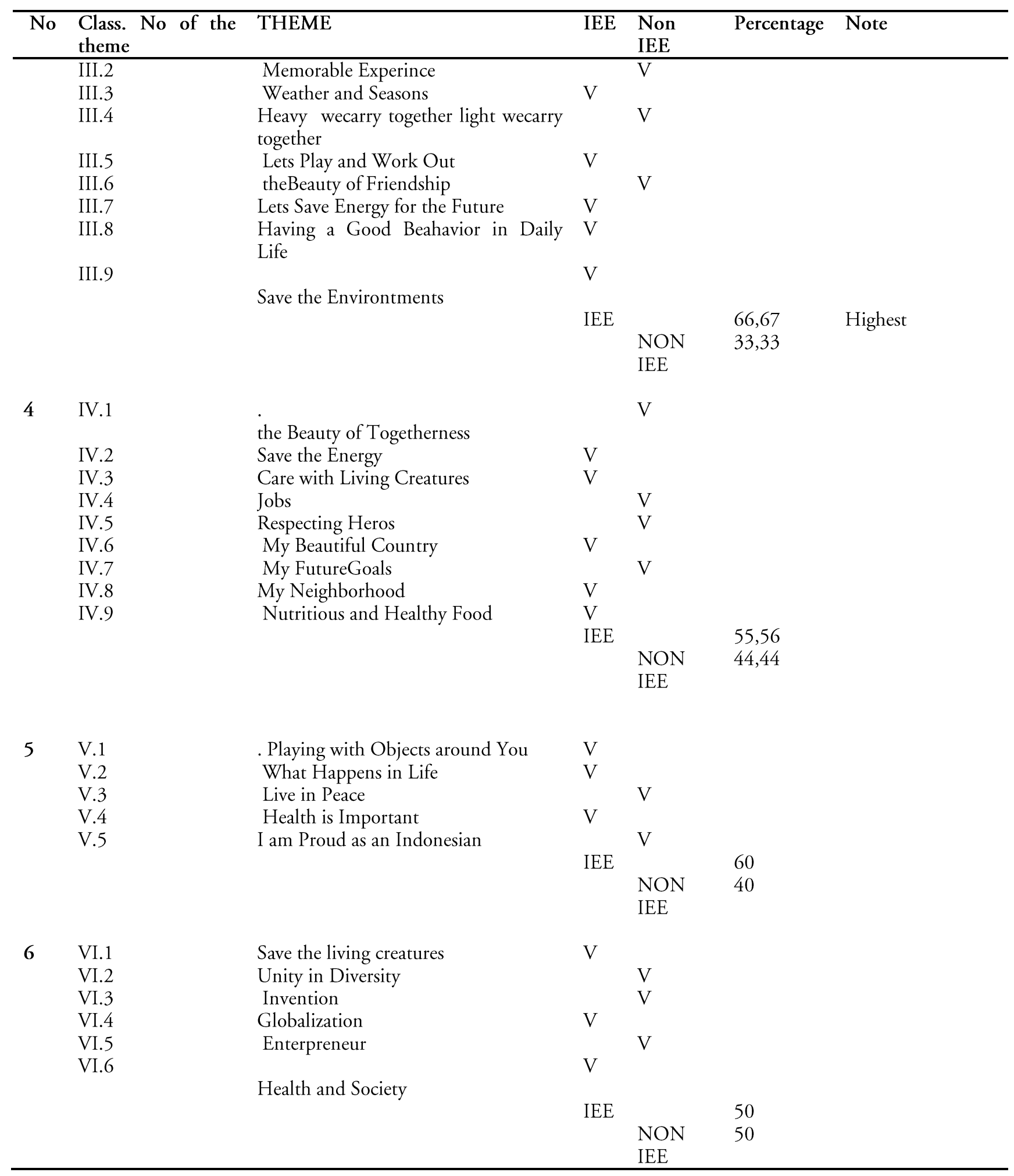

Based on the analysis of the themes in the table, all pieces have included indicator values from Islamic Environmental Ethics according to Manoiu, Shaikh, and Harahap. The above research found that the theme in the first grade has the lowest percentage in the IEE vocabulary, which is $37.5 \%$. Therefore, the theme of the first grade was chosen to be designed for learning. Taking the piece in the first grade is intended to enrich and give meaning to learning with Islamic 
Environmental Ethics integration. The highest per cent is in the third grade. The class isn't chosen to be developed because the quality is "environmental kindly" enough. The implementation framework is presented in the following table 2 .

Table 2. The Implementation of Islamic Environmental Ethics-Based Math Learning

\begin{tabular}{|c|c|c|c|}
\hline $\begin{array}{c}\text { BASIC } \\
\text { COMPETEN } \\
\text { CY/GRADE }\end{array}$ & IEE & $\begin{array}{c}\text { ACTIVITY } \\
\text { (THEMATICAL/I } \\
\text { NDIVIDUAL) }\end{array}$ & $\begin{array}{c}\text { ASSESMEN } \\
T\end{array}$ \\
\hline $3.5 / 1$ & $\begin{array}{l}\text { Hadith } \\
\text { About 3r } \\
\text { Usage/Cle } \\
\text { anliness }\end{array}$ & $\begin{array}{l}\text { Playing With } \\
\text { Numerical } \\
\text { Patterns From } \\
\text { Second-Hand } \\
\begin{array}{l}\text { Objects In } 3 \mathrm{r} \\
\text { Principle }\end{array}\end{array}$ & $\begin{array}{l}\text { RUBRIC/W } \\
\text { RITTEN } \\
\text { TEST }\end{array}$ \\
\hline $4.5 / 1$ & $\begin{array}{l}\text { Hadith } \\
\text { About 3r } \\
\text { Usage/Cle } \\
\text { anliness }\end{array}$ & $\begin{array}{l}\text { Making And } \\
\text { Predicting The } \\
\text { Numerical } \\
\text { Patterns With } \\
\text { Second-Hand } \\
\text { Objects In } 3 r \\
\text { Principle }\end{array}$ & ACTION \\
\hline $3.6 / 1$ & $\begin{array}{l}\text { Hadith } \\
\text { About 3r } \\
\text { Usage/Cle } \\
\text { anliness }\end{array}$ & $\begin{array}{l}\text { Playing With 2d } \\
\text { And 3d Shapes } \\
\text { From Second- } \\
\text { Hand Object }\end{array}$ & $\begin{array}{l}\text { QUESTIO } \\
\text { NER }\end{array}$ \\
\hline $4.6 / 1$ & $\begin{array}{l}\text { Hadith } \\
\text { About 3r } \\
\text { Usage/Cle } \\
\text { anliess }\end{array}$ & $\begin{array}{l}\text { Classifying } 2 \mathrm{~d} \\
\text { Shapes With } \\
\text { Second-Hand } \\
\text { Objects }\end{array}$ & ACTION \\
\hline
\end{tabular}

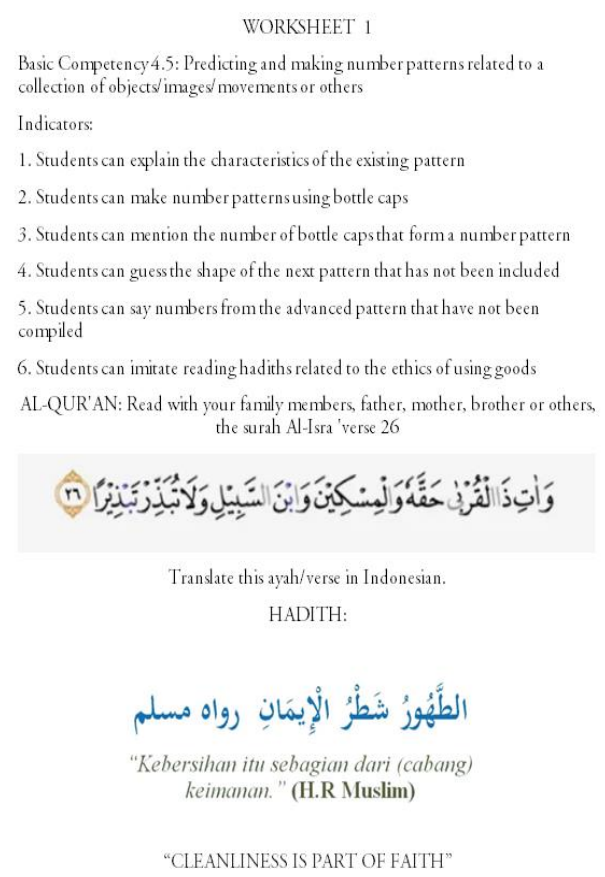

Math Learning Worksheets with Islamic Environmental Ethics

The compiled worksheet consists of 2 worksheets, namely: 1) Worksheet 1: Activity playing on number pattern, using the colorful bottle cap s; 2) Worksheet 2: Activity of grouping the one-dimensional shape using the second hand or recycle goods.

Islam strongly encourages its people to become caring people because God hates those who make mischief. This is as written in the Qur'an QS 28:77; QS. 2:60 For that reason, in the worksheet, using goods display in the form of bottle caps and the shopping goods boxes is a part of the maintenance behavior, using goods that are not used. Activities consist of: 1) Play the bottle cap; 2) Arrange the pattern of the bottle cap; 3) Continuing the pattern composed from the bottle cap; 4) Prepare test equipment and materials: make visual aids from flat items; 5) Draw a flat shape, cut and color it; 6) Read the ayah \& hadith of Islamic Environmental Ethics with parents/family.

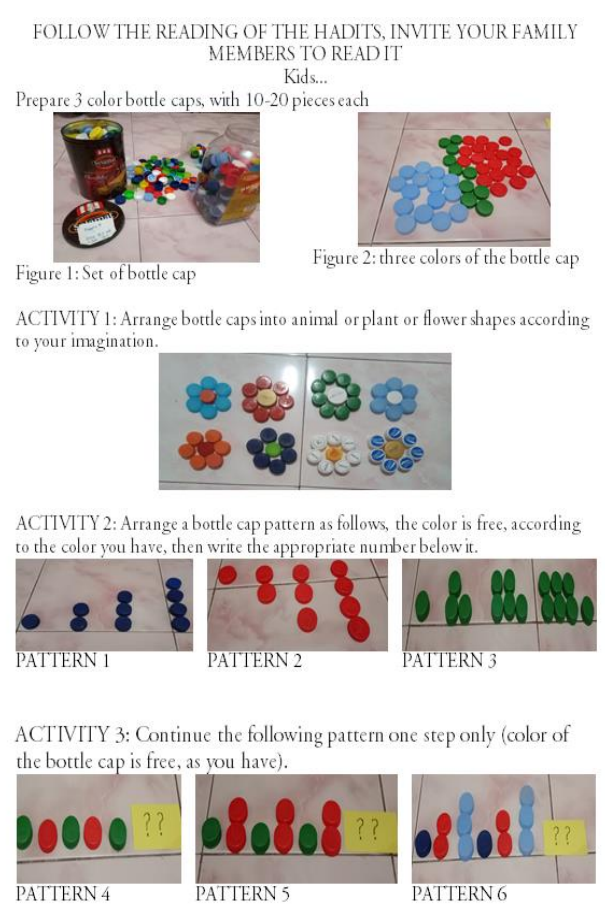

Figure 1: Worksheet 1 about the activity with bottle caps 


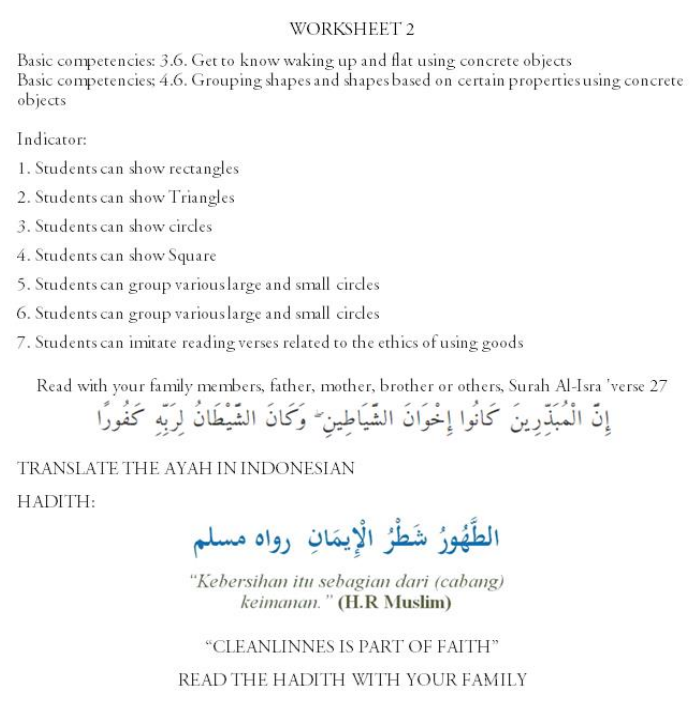

READ THE HADITH WITH YOUR FAMILY

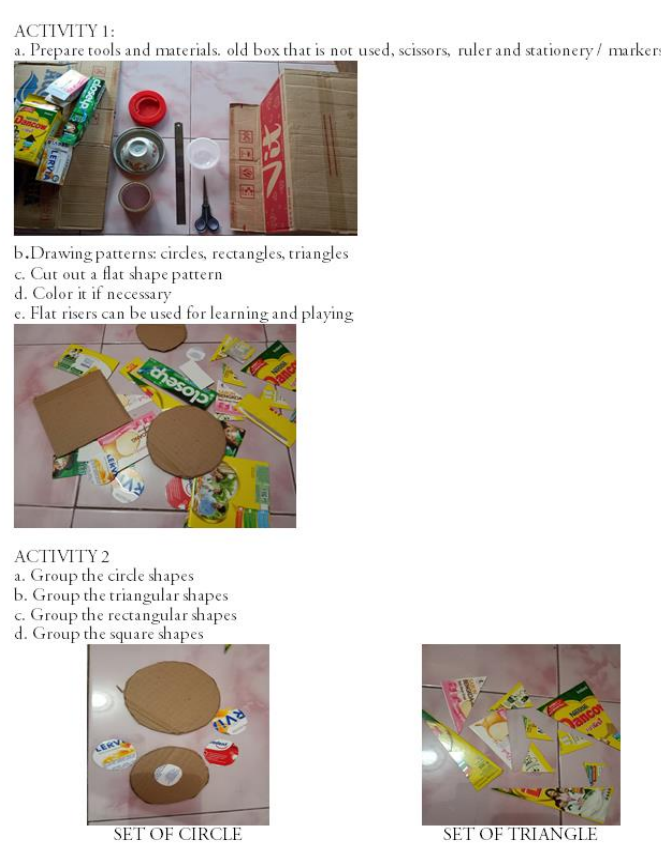

Figure 2: Worksheet 2 about the activities: making geometric pattern, cutting and grouping onedimensional shape with shopping goods boxes

Cleanlinnes in Islam is so important, in God's Messengers, there are comprehensife aspects: material, spiritual and also ritual aspect (Kuscular,2008; Kiani et al, 2015; Muftic, 1997) It is essentially to campaign for student about cleanlinnes with the hadith. In other side, Allah doesn't like those who commit excess (QS 7: 31: Adi \& Puspitasari (2016). And Islam avoid wasteful activities, as in Qur'an QS.17:26-27, because the wasteful are brothers of devils (Kula, 2001) With this reason, the developed worksheets, show and use the ayahs about the wasteful,and the hadith about cleanlinnes.

Green tools or green learning media using botle caps have had used by Cindy Logan for math learning.( https://id.pinterest.com/algebrat eacher/mathbottle-cap-math/) It makes sense that the color and the variation of the shape can make the student happy in the math learning. The teacher should develop to explore the learning media with ussed goods,so they can develop the math learning while save the earth. Why student must learning about pattern? Learning patterns can train logical thinking and develop creativity (Mauluah, 2008). Learning by using a well-known visual, close to students' daily problems, can help students understand the concepts being learned (Prahmana, et al, 2012); (Freudenthal, 1991)) used bottle caps learning patterns are theoretically justified and have a strong foothold in learning mathematics. Also, it is an excellent alternative activity for students to use the boxes that cut forming one-dimensional shapes.

\section{The Implementation of Islamic Environmental Ethics in elementary school for first grade}

Implementation of learning using Islamic Environmental Ethics principles in mathematics learning that has been carried out consists of: a) Cultivation of environmental awareness based on Islamic values; b) Students' activities in reading hadith are related to environmental awareness, especially the use of goods; c) Student activities use objects with the $3 \mathrm{R}$ principle; d) Practice recognizing patterns and classifying flat shapes; e) Reflection in the form of recalling that has been done in learning, and taking the benefits of the use of used items and orders from the hadith not 
to become a wasteful; f) Students' reflections that are using used items to be used are part of carrying out God's commands, and the Apostle; g) Student's reflection that using used items means students have implemented values in religion (Islam).

\section{Implementation of Islamic Environmental Ethics for preschool; elementary and secondary}

The implementation of learning at various levels of education, associated with the environment, has many benefits and positive effects. (Erdogan, 2015; Ozsoy, et al, 2012; Mayasari, Natsir \& Munfarikhatun, 2019; Zaenuri et al, 2017; Wuryastuti \& Ni'mah, 2013) Benefits and effects according to the researchers, among others, regarding environmental literacy, capabilities in problemsolving, clean living habits, and life skills. The researchers have not found any use of education related to the environment, which is about awareness of the existence of his Lord, as well as awareness about the presence of a Creator or the understanding of carrying out the religious orders they hold.

As for this research, by using the reflection step, it was found that there was a student's awareness to use used items as items that could use for learning, as part of carrying out good deeds, carrying out the commands of God and His Apostles. This has become the advantage of the integration of religious values in learning, especially mathematics learning. Material content can be achieved, but students can also obtain the awareness of spiritual values.

\section{Conclusion}

The design of integrating Islamic Environmental Ethics values in the first year mathematics learning can be done through meaningful learning activities. Competencies that can be achieved are found in basic competencies
3.5, 4.5, 3.6 and 4.6. The IEE value used is the prophet's hadith about cleanliness

In addition, two worksheets are developed in this research. The worksheet guide the student for math learning based on the IEE value. The IEE value that is implemented is about earth care. Therefore concern for the earth can be compiled: namely the use of used goods in the form of colorful bottle caps and used materials for learning mathematics. Further research can develop the worksheets for upper classes based on IEE, it can also criticize this paper because it has not gone through the Develop and Disseminate stages from $4 \mathrm{D}$ stages of Thiagarajan.

\section{Acknowledgements}

The first author wishes to thank the Indonesian Ministry of Religious Affairs (MORA) that supporting the 5000 Doctoral Scholarship for the Research.

\section{References}

Adi, S. M., \& Puspitasari, C. (2016). Mosque as a model of learning principles of sustainable architecture. Journal of Islamic Architecture, 4(1), 33-36.

Ashokan, V., Venugopal, K. (2016). Impact of Thematic Approach on Communication Skill in Preschool. Imperial Journal of Interdisciplinary Research (IJIR), 2(10). 394397. https://eric.ed.gov/ ?id=ED581398

Dilao, R. (2004). Mathematical models in population dynamics and ecology. In Biomathematics: Modelling and Simulation, Publisher: World Scientific.

Erdogan. M (2015) The Effect of Summer Environmental Education Program (SEEP) on Elementary School Students' Environmental Literacy (International). Journal of Environmental \& Science Education, 10(2), 165-18.

Freudenthal, H. (1991). Revisiting Mathematics Education: China Lectures. Dordrecht: Kluwer Academic Publishers.

Gul \& Ali (2018) An Islamic Approach towards environmental protection. Journal of Law and 
Society LAw College, XLIX(73). University of Peshawar.

Harahap. H.R.Z. (2015) Etika Islam Dalam Mengelola Lingkungan Hidup; Jurnal EduTech 1(1).

Jianguo, M. (2004). Teaching Environmental Awareness in Mathematics. Chinese Education \& Society, 37(4), 53-56.

Kasiyati. K., Zulmiyetri (2018) Integrated Thematic Learning through Contextual Learning to Improve Performance of Students with Mild Intellectual Disability; Journal of Educational and Learning Studies, 1(1).

Khalid, F., Ali Kh. Thani. (2007). Teachers Guide Book for Islamic Environmental Education. The Islamic Foundation for Ecology and Environmental Sciences 93 Court Road, Balsall Heath Birmingham B12 9LQ Englande.

Khalid, F. (2010). Islam and the Environment Ethics and Practice an Assessment. Religion Compass, 4(11), 707-716. https://doi.org /10.1111/j.1749-8171.2010.00249.x

Manoiu, et al (2016) A Qualitative Exploration of the Holy Quran's Environtmental Teaching; IJAEDU-International E-Journal of Advances in Education, 2(5).

Marantika, V.L. (2018) Perbandingan Keakurasian Model Eksponensial dn Model Logistik pada Pertumbuhan Penduduk Miskin di Daerah Bandar Lampung.Digital Repository UNILA: http://digilib.unila.ac.id/id/eprint/29871

Mauluah, L. (2008) Relasi Berulang dan Penggunannya di Pendidikan Dasar,Menengah dan Perguruan Tingg. Jurnal ALGORITMA; Jurnal Matematika dan Pendidikan Matematika. Penerbit: CeMED Jurusan Pendidikan Matematika FakultasIlmuTarbiyah dan Keguruan UIN Syarif Hidayatullah Jakarta

Mayasari, D., Natsir I., Munfarikhatin A. (2019) Improving capability of student based on green mathematics through nation character education for caring the environment. IOP Conf. Series: Earth and Environmental Science 343 (2019) $012215 \quad$ IOP Publishing doi:10.1088/1755-1315/343/1/012215

McCrea, E.J. (2010). The Roots of Environmental Education: How the Past Supports the Future.
Environmental Education and Training Partnership, 1-12. http://cms.eetap.org/repository/moderncms_d ocuments/History.Final.20060315.1.1.pdf

Mohamed, N. (2012). Revitalising an Eco-Justice Ethic of Islam by way of Environmental Education: Implications for Islamic Education; Stellenbosch University http://scholar.sun.ac.za

Ozsoy,S., Ertepinar, H., Saglam, N. (2012). Can eco-schools improve elementary school students' environmental literacy levels? AsiaPacific Forum on Science Learning and Teaching, 13(2).

Prahmana, R. C. I., Zulkardi, Hartono, Y. (2012). Learning multiplication using Indonesian traditional game in third grade. Journal on Mathematics Education, 3(2), 115-132.

Sarvestan, A.A., Shahvali, M. (2008) Environmental Ethics: Toward an Islamic Perspective; American-Eurasian J. Agric. \& Environ. Sci., 3 (4): 609-617.

Shaikh., S.A (2018); Exploring the Significance of Islamic Environmental Ethics for Fostering Sustainable Environment. Journal of Islamic Banking and Finance, 35(1).

Sontag. Sontag, E.D, (2005) Lecture Notes in Mathematical Biology; Rutgers University http://www.di.univr.it/documenti/OccorrenzaI $\mathrm{ns} / \mathrm{matdid} /$ matdid262230.pdf

Spiegel, M., John Schille, J., Srinivasan, A. (2002) Probability and Statistics. Publisher: McGrawHill; 1 edition.

Ulum, C. (2018) Keterampilan Sosial Peserta Didik Dalam Pembelajaran Tematik Di Kelas V Mi Muhammadiyah Selo Kulon Progo; AlBidayah: Jurnal Pendidikan Dasar Islam, 10(2).

Wuryastutii, S., Ni'mah,I. (2013) Model Pembelajaran Berbasis Lingkungan Untuk Meningkatkan Kecakapan Hidup Mahasiswa Melalui Pembuatan Kompor Biogas (Penelitian pada Pembelajaran Mata Kuliah Konsep Dasar Biologi di UPI Kampus Serang) ; EduHumaniora, 5(2).

Zaenuri.et al. (2017) Habituation Model Of Implementing Environmental Education In Elementary School; JPII, 6(2), 206-212; http://journal.unnes.ac.id/index.php/jpii. 